Review

\title{
Occurrence of filamentous fungi in drinking water: their role on fungal-bacterial biofilm formation
}

\author{
Tiago Barros Afonso, Lúcia Chaves Simões, Nelson Lima* \\ CEB, Centre of Biological Engineering, University of Minho, Braga, Portugal
}

\section{A R T I C L E I N F O}

\section{Article history:}

Received 30 June 2020

Accepted 9 November 2020

Available online 13 November 2020

\section{Keywords:}

Drinking water

Fungi

Bacteria

Biofilms

Fungal-bacterial interactions

\begin{abstract}
A B S T R A C T
Water is indispensable to life and safe and accessible supply must be available to all. The presence of microorganisms is a threat to this commitment. Biofilms are the main reservoir of microorganisms inside water distribution systems and they are extremely ecologically diverse. Filamentous fungi and bacteria can coexist inside these systems forming inter-kingdom biofilms. This review has the goal of summarizing the most relevant and recent reports on the occurrence of filamentous fungi in water distribution systems along with the current knowledge and gaps about filamentous fungal biofilm formation. Special focus is given on fungal-bacterial interactions in water biofilms.
\end{abstract}

๑ 2020 Institut Pasteur. Published by Elsevier Masson SAS. All rights reserved.

\section{Introduction}

Water is indispensable to life. Therefore, every effort should be done to achieve drinking water as safe as possible. The United Nations Sustainable Development Goal 6 (SDG 6) reinforces that "While substantial progress has been made in increasing access to clean drinking water and sanitation, billions of people - mostly in rural areas still lack these basic services. Worldwide, one in three people do not have access to safe drinking water, two out of five people do not have a basic hand-washing facility with soap and water" [1]. This becomes even more dramatic in times of SARS-Cov2 where access to clean water and handwashing with soap are crucial to controlling the individual and communitarian pandemic disease of COVID-19. Clean water is still a luxury for poor regions. For this reason, water companies have the main goal of delivering microbiological safe water to the consumers, adequate in quantity and delivery pressure and satisfactory in terms of taste, odour and appearance [2]. This objective can be questioned when microorganisms are present in excess as their growth may affect the organoleptic properties of the water. These microorganisms can be found either as in planktonic forms inhabiting bulk water or as biofilms growing on pipes surfaces [3]. Biofilms can be considered the main source of microorganisms in drinking water distributions

\footnotetext{
* Corresponding author. University of Minho, Centre of Biological Engineering, Campus de Gualtar, 4710-057, Braga, Portugal. Fax: +351 253604429.

E-mail address: nelson@ie.uminho.pt (N. Lima).
}

systems (DWDS) and are responsible for serious effects, such as changes in the taste, turbidity, colour and odour of the water, corrosion of metallic pipes, disinfectant demand, potential accumulation and dispersion of pathogens and production of toxins [4,5]. Primary and opportunistic pathogens are found in DWDS because they can survive water disinfection. Special protection is provided to microorganisms embedded in biofilms such as sharing of nutrients and metabolic products and increased resistance to environmental stresses, such as hydrodynamic shear forces and disinfection [6]. Under natural conditions, true monospecies biofilms are rare, and consequently, they are usually considered as complex communities [7]. The ecology of a biofilm is a complex function of prevailing growth conditions, hydrodynamic shear forces and presence of microbial metabolites and molecules, such as cell-cell signalling communication molecules, excreted by its inhabitants [8]. This diversity leads to a variety of complex interactions between the microorganisms that are present. Findings into the microbial ecology of DWDS have shown that resistance of microorganisms to disinfectants, particularly chlorine, is affected by this microbial diversity [9]. This information, has, however, been mainly obtained from studies with bacteria. Studies regarding fungi, in particular filamentous fungi, have been gaining attention due to their biofilm formation ability, however, their interaction with bacteria in fungal-bacterial biofilms is still poorly understood.

This review has the goal of summarizing the most relevant and recent reports on the occurrence of filamentous fungi in water distribution systems along with the current knowledge and gaps about filamentous fungal biofilm formation. Special focus on 
fungal-bacterial interactions in biofilms is provided given the latest findings on this topic.

\section{Fungi and filamentous fungi biofilms}

Fungi are a diverse and abundant group of organisms belonging to the kingdom Eumycota [10]. The most recent classification of this kingdom comprises seven recognised phyla: Basidiomycota, Ascomycota, Glomeromycota, Microsporidia, Blastocladiomycota, Neocallimastigomycota and Chytridiomycota [11]. Fungal classification is, however, very dynamic, as shown by the recently proposed phyla Cryptomycota [12]. As a practical approach to the classification of fungi, division regarding their cellular organisation has been made. They range from microscopic single-cell species (yeasts) to species with massive mycelia. This latter large group of organisms can be characterised by hyphal growth supporting macroscopic sexual reproductive structures (e.g., truffles, mushrooms) and microscopic sexual or asexual reproductive structures, known as moulds or filamentous fungi [13]. Fungi are ubiquitous and some of them, belonging to the phyla Chytridiomycota, are particularly adapted to aquatic environments. These fungi are known for producing zoospores morphologically apt to propagate in running waters. Filamentous fungi from other phyla in Eumycota are, however, mostly adapted to the terrestrial environment, such as soil and anything in interface with air, as they generally need a solid substrate for spore dispersal [14]. Although DWDS are not considered natural habitats for these filamentous fungi, they can often be introduced into these environments from different pathways, such as physical openings in storage facilities, treatment breakthroughs, leaking joints and adapters, cracks in pipelines and/or during maintenance or mains installation. Sammon et al. [15] demonstrated that airborne spores can be an important external source of filamentous fungi propagules in a DWDS. Once inside these systems, fungi can survive the oligotrophic conditions by scavenging nutrients from the substrate which they colonize or the water in which they are inhabiting. Consequently, their presence may then cause additional problems to the water quality (e.g., unpleasant appearance with flocs and earthy pungent odours, the presence of pigments, pipe blockage, a source of potentially pathogenic and allergy-causing fungi and the presence of mycotoxins) [5,6,16-19]. To maximize nutrient uptake, filamentous fungi will form hyphal mats. Due to their absorptive nutrition mode, secretion of extracellular enzymes that digest complex molecules and apical hyphal growth, filamentous fungi have a high ability to grow on surfaces, thus forming biofilms [20]. Fungal survivability and proliferation in DWDS are believed to be related to the ability to form biofilms [21].

Harding et al. [22] proposed a six-step pioneer model for filamentous fungal biofilm formation based on models for bacteria and yeasts: 1) propagule adsorption, 2) active attachment to a surface, 3 ) microcolony formation I, 4) microcolony formation II (or initial maturation), 5) maturation and, 6) dispersal (planktonic phase). Recently, Fernandes et al. [23] updated this model by adding an initial step - surface conditioning - where the surface hydrophobicity and charge of spores and the substratum play key roles in the adhesion process. This initial physical contact can result in reversible adhesion, followed by irreversible adhesion with the secretion of adhesive substances by germinated spores and active germlings [22]. Spore germination will ensue if suitable environmental conditions are met [23]. After germlings start to form, they secrete hydrophobins that mediate adhesion and hyphae-substratum interaction [24]. Subsequently, hyphal differentiation produces a complex hyphae net (mycelium) that grows in all directions enclosed within a polymeric extracellular matrix, where quorumsensing molecules, similarly to bacterial biofilms, are present [25]. The maturation stage for DWDS biofilms should mainly occur in reservoirs due to the requirement of a stable air-water interface for aerial growth and subsequent spore formation and air dispersion [10]. Finally, the dispersion stage occurs through the release of spores or different propagules in response to environmental stresses or biological stimuli [22]. In drinking water, propagules can be dispersed by water flow, which can then establish new biofilms, further spreading the presence of filamentous fungi in drinking water $[15,23,26]$.

\section{Occurrence of filamentous fungi in DWDS}

Since the 70s, several works have reported the presence of filamentous fungi in WDS worldwide. Table 1 lists and focuses only on the most relevant reports from the last two decades. A wide diversity of filamentous fungi has been isolated/detected from drinking water. The most frequent recovered species belong to the genera Aspergillus, Cladosporium and Penicillium (Table 1). This might be related to their ability to secrete a pigment called melanin, which confers protection to spores against a variety of stresses, providing these microorganisms with a competitive advantage and greater resistance to water treatment [6]. In addition, due to the hydrophobicity property of the spores from these genera, further protection is offered against water disinfection as spores tend to aggregate between each other and other particles [6].

Among the isolated filamentous fungi, potentially pathogenic, allergenic and toxigenic species have also been found. This is particularly concerning since several reports on the presence of these fungi have been obtained from hospital water systems $[29,30,32,44,45,49,51,53]$. In some cases, the presence of pathogenic species (e.g. Aspergillus fumigatus; Fusarium solani) in drinking water, has led to the hypothesis of hospital water systems serving as transmission routes for fungal infections. These results indicate that hospital water contains high fungal diversity, including potential pathogens. Many of the fungal species found in drinking water have also allergenic potential [5]. Fungal species from the main genera recovered from drinking water have also been investigated towards their implication with asthma and other respiratory problems, regarding indoor environments [60]. Some of these health adverse effects may arise not only from the fungi itself but also from the production of secondary metabolites and volatile organic compounds (VOC's). Several species from both Penicillium and Aspergillus genera are known mycotoxin producers. Mycotoxins cause a variety of health problems and are known to be carcinogenic and capable of impairing the immune system in both humans and animals [61]. Of all the different mycotoxins that can be produced, aflatoxins (Aspergillus spp.) and zearalenone (Fusarium spp.) are some of the most relevant and have been detected in drinking water $[5,62]$. The concentration of mycotoxins in drinking water is likely to be very diluted and, for the time being, has not been identified as the source of symptoms attributable to mycotoxins.

For an in-depth understanding of the occurrence, ecology and physiology of fungal contaminants in drinking water, Novak Babič et al. $[61,63]$ recently compiled this information in reviews. It focuses on reports from European water sources in the last 30 years, including surface-, ground- and tap-water intended for human consumption.

\section{Methodology progression to study fungi in drinking water: emphasis on biofilms}

The methodology used to study fungi in drinking water is key to fully understand the real dimension and significance of their occurrence. A high variation on how the analyses are performed is a major issue when trying to compare different studies. This is due to 
Table 1

Most relevant filamentous fungi surveys in drinking water from the last two decades.

\begin{tabular}{|c|c|c|c|c|}
\hline Location, Date & Water source & Isolation method & Most frequent fungal genera & References \\
\hline United Kingdom, 1996 & Surface water and network & $\begin{array}{l}\text { Membrane filtration, } \\
\text { centrifugation, direct plating }\end{array}$ & $\begin{array}{l}\text { Aspergillus, Cladosporium, Epicoccum, } \\
\text { Penicillium and Trichoderma }\end{array}$ & [27] \\
\hline $\begin{array}{l}\text { United States of America } \\
\text { (Springfield, MO), } 1997\end{array}$ & Municipal water supply system & Pipe coupons (Biofilm) & Aspergillus and Penicillium & [28] \\
\hline Greece (Thessaloniki), 1998 & Hospital and community tap water & Membrane filtration & Acremonium, Aspergillus and Penicillium & [29] \\
\hline (Haemodialysis units) & $\begin{array}{l}\text { Municipal water supplies of } \\
\text { haemodialysis centres }\end{array}$ & Membrane filtration & Aspergillus and Penicillium & [30] \\
\hline $\begin{array}{l}\text { Germany (North Rhine- } \\
\text { Westphalia), 1998-99 }\end{array}$ & Drinking water & Pour-plating & $\begin{array}{l}\text { Acremonium, Exophiala, Penicillium and } \\
\text { Phialophora }\end{array}$ & [31] \\
\hline Norway (Oslo), 1998-99 & Hospital tap and shower water & $\begin{array}{l}\text { Membrane filtration and swabs } \\
\text { from water-related surfaces }\end{array}$ & $\begin{array}{l}\text { Aspergillus, Cladosporium, Paecilomyces and } \\
\text { Trichoderma }\end{array}$ & [32] \\
\hline $\begin{array}{l}\text { United States of America (Little } \\
\text { Rock, AR), 1997-2000 }\end{array}$ & Water distribution system of a Hospital & $\begin{array}{l}\text { Membrane filtration, swab } \\
\text { applicators }\end{array}$ & $\begin{array}{l}\text { Alternaria, Aspergillus, Paecilomyces and } \\
\text { Penicillium }\end{array}$ & {$[33,34]$} \\
\hline (Houston, TX), 2000 & Water distribution system of a Hospital & $\begin{array}{l}\text { Membrane filtration, } \\
\text { centrifugation, swab applicators }\end{array}$ & Fusarium & [35] \\
\hline $\begin{array}{l}\text { Greece (Thessaloniki, Athens } \\
\text { and Heraklion), } 2000\end{array}$ & Hospital tap water & Membrane filtration & $\begin{array}{l}\text { Acremonium, Fusarium, Paecilomyces and } \\
\text { Penicillium }\end{array}$ & [36] \\
\hline Poland (Warsaw), 2000-02 & Municipal water supply system & Membrane filtration & Aspergillus, Cladosporium and Fusarium & [37] \\
\hline Norway, 2002-03 & Drinking water (surface and groundwater) & Membrane filtration & Aspergillus, Penicillium and Trichoderma & {$[16,38,39]$} \\
\hline Turkey (Istanbul), 2003 & Water distribution system of a Hospital & Membrane filtration & Acremonium, Aspergillus and Penicillium & [40] \\
\hline Portugal (Braga), 2003-04 & Tap water & $\begin{array}{l}\text { Membrane filtration and } \\
\text { swabbing }\end{array}$ & Acremonium and Penicillium & [41] \\
\hline Belgium (Liège), 2005-06 & Water distribution system of a Hospital & Membrane filtration & $\begin{array}{l}\text { Aspergillus, Fusarium, Paecilomyces and } \\
\text { Penicillium }\end{array}$ & {$[42]$} \\
\hline Austria, 2006 & Drinking water and groundwater & Membrane filtration and plating & Cladosporium and Penicillium & [43] \\
\hline \multirow[t]{2}{*}{ Brazil (São Paulo), 2006} & $\begin{array}{l}\text { Water distribution system of a } \\
\text { haemodialysis unit }\end{array}$ & Membrane filtration & $\begin{array}{l}\text { Aspergillus, Cladosporium, Fusarium and } \\
\text { Trichoderma }\end{array}$ & [44] \\
\hline & $\begin{array}{l}\text { Water distribution system of a } \\
\text { haemodialysis centre }\end{array}$ & Membrane filtration & $\begin{array}{l}\text { Aspergillus, Fusarium, Penicillium and } \\
\text { Trichoderma }\end{array}$ & {$[45]$} \\
\hline Portugal (Lisbon), 2006-08 & $\begin{array}{l}\text { Surface, spring and groundwater for the } \\
\text { production of drinking water }\end{array}$ & $\begin{array}{l}\text { Membrane filtration, spread plate } \\
\text { and pour plate }\end{array}$ & Aspergillus, Cladosporium and Penicillium & {$[46,47]$} \\
\hline $\begin{array}{l}\text { Australia (Rockhampton), } \\
\text { 2007-08 }\end{array}$ & Municipal water supply system & Membrane filtration & $\begin{array}{l}\text { Aspergillus, Cladosporium, Fusarium and } \\
\text { Penicillium }\end{array}$ & [48] \\
\hline $\begin{array}{l}\text { Australia (Rockhampton), } \\
\text { 2007-10 }\end{array}$ & Municipal water supply system & $\begin{array}{l}\text { Glass, PVC and concrete coupons } \\
\text { (Biofilm) }\end{array}$ & Aspergillus, Cladosporium and Penicillium & [15] \\
\hline Brazil (São Paulo), 2007-08 & $\begin{array}{l}\text { Water distribution system of paediatric } \\
\text { haematopoietic stem cell units }\end{array}$ & Membrane filtration & $\begin{array}{l}\text { Aspergillus Cladosporium, Penicillium and } \\
\text { Purpureocillium }\end{array}$ & [49] \\
\hline Portugal (Centre), 2008-12 & $\begin{array}{l}\text { Untreated water (groundwater, spring } \\
\text { and surface water) }\end{array}$ & Membrane filtration & Penicillium and Trichoderma & [50] \\
\hline Italy (Marche region), 2010-11 & $\begin{array}{l}\text { Water treatment and distribution system } \\
\text { of haemodialysis units }\end{array}$ & Membrane filtration & Alternaria, Cladosporium and Tricophyton & [51] \\
\hline Brazil (São Paulo), 2011-12 & Tap water from wells (groundwater) & Membrane filtration & $\begin{array}{l}\text { Acremonium, Aspergillus, Fusarium and } \\
\text { Penicillium }\end{array}$ & [52] \\
\hline China (Xiamen), 2011-12 & Drinking water (surface and tap water) & Membrane filtration & $\begin{array}{l}\text { Aspergillus, Fusarium, Penicillium, Phialophora } \\
\text { and Trichoderma }\end{array}$ & [17] \\
\hline $\begin{array}{l}\text { United States of America } \\
\quad \text { (Pittsburgh, PA), 2011-12 }\end{array}$ & Hospital hot water system & Membrane filtration & $\begin{array}{l}\text { Aspergillus, Cladosporium, Penicillium, } \\
\text { Peniophora and Rhodosporidium }\end{array}$ & [53] \\
\hline $\begin{array}{l}\text { Brazil (Recife), 2013-14 and } \\
\quad 2015\end{array}$ & Water distribution system (groundwater) & Membrane filtration & $\begin{array}{l}\text { Aspergillus, Fusarium, Penicillium and } \\
\text { Trichoderma }\end{array}$ & [54] \\
\hline $\begin{array}{l}\text { United States of America } \\
\qquad \text { (Anonymous), 2014, } 2016\end{array}$ & Drinking water treatment plant & Membrane filtration & $\begin{array}{l}\text { Alatospora, Aspergillus, Penicillium, Taphrina } \\
\text { and Tuber }\end{array}$ & [55] \\
\hline $\begin{array}{l}\text { China (Guangdong Province), } \\
2015\end{array}$ & $\begin{array}{l}\text { Water supply reservoirs, drinking water } \\
\text { treatment plants }\end{array}$ & Direct plating & Aspergillus and Cladosporium & [18] \\
\hline Colombia, 2015 & Drinking water network (surface water) & $\begin{array}{l}\text { Water-surface interface scraping } \\
\text { (Biofilm) }\end{array}$ & Paecilomyces, Paraconiothyrium and Penicillium & [56] \\
\hline $\begin{array}{l}\text { United Kingdom (Southwest } \\
\text { region), 2014-15 }\end{array}$ & $\begin{array}{l}\text { Surface and groundwater chlorinated } \\
\text { networks (bulk water and biofilms) }\end{array}$ & Membrane filtration & $\begin{array}{l}\text { Aspergillus, Basiodobolus, Cladosporium, } \\
\text { Plectosphaerella, and Rhexocercosporidium }\end{array}$ & {$[7,57]$} \\
\hline Poland (Lodz), 2016 & Recreational surface water & Centrifugation & Alternaria, Aspergillus and Penicillium & [58] \\
\hline Spain (Valencia), 2019-20 & Drinking water network & Membrane filtration & Aspergillus and Cladosporium & [59] \\
\hline
\end{tabular}

the lack of a uniform approach for detection or isolation of fungi. The most usual isolation pathways for analysing fungi in drinking water are based on water filtration followed by either conventional culturing methods or molecular approaches. Membrane filtration techniques are the most usually employed (Table 1) with varying volumes of water. Other techniques performed include direct plating with low volumes of water as well as centrifugation $[18,31,35,58]$.

Since there is no standardisation approach in the isolation of fungi, the culture medium used tends to vary among researchers. Among the most commonly reported media are Sabouraud dextrose agar (SDA), Sabouraud glucose agar (SGA), malt extract agar (MEA), cornmeal agar (half-strength) (CMA/2), Czapek Dox agar (CZ), Dichloran 18\% glycerol agar (DG18), Dichloran Rose Bengal Chloramphenicol agar (DRBC), Neopeptone glucose Rose Bengal aureomycin (NGRBA) and potato dextrose agar (PDA) $[41,43,64]$. Some of these media have higher nutrition content than others, thus being more selective towards some fungal species. Hence, an extensive culturomics approach, applying different designed media, should be used in order to increase the probability of obtaining the highest coverage representation of the fungi present in water. As pure fungal cultures are obtained, the 
identification of fungi is usually performed through morphological identification keys, which could lead to misidentification at the species level. For instance, if the fungi do not sporulate, it cannot be identified morphologically. To improve this step, molecular approaches such as PCR and sequencing were employed. The recommended genetic marker for basic fungal identification is the internal transcribed spacer (ITS) region which has already been used in the majority of studies [3,39,47,65,66]. However, there are limitations in separating all fungal species when using only this genetic barcode, with high relevance for Aspergillus and Penicillium genera. Hence, secondary markers such as the $18 \mathrm{~S}$ ribosomal small subunit, $\beta$-tubulin or the translation elongation factor 1 -alpha (TEF$1 \alpha$ ) should be added in complementation [39,57,67].

Biofilm sampling from DWDS has evolved with time. The most usual method of sampling has been performed by scrapping or swabbing water related surfaces $[32,33,35,41,56,68]$. Swabs were then directly plated onto solid media or previously suspended in a sterile saline solution before being plated. Other methods for studying biofilms in situ include cutting out pipes, which could then be placed onto medium for culturing, or the use of sampling devices inserted into the pipe (Fig. 1) [3,26,57,64].

Pipe cut-out is, however, considered as a destructive sampling method and has other disadvantages, such as being expensive and labour-intensive. It is also difficult to repeat the experiment since pipe cut-outs have to be replaced after sampling [64,69]. The use of devices inserted into pipes is, therefore, the currently preferred sampling method. These devices are usually coupons of different materials such as glass, polyvinyl chloride (PVC), polyethylene, acetate, cast-iron or concrete, to encompass the high variability of materials present in DWDS $[3,7,15,26]$. The majority of older DW networks were made of iron-based materials. More recently, polymeric materials such as PVC have been preferred because they are easier to handle. Different materials have different surface physicochemical properties that influence biofilm formation, including microbial diversity [70-72]. Shortly, physical adsorption is generally a reversible process in which one monolayer is formed and involves nonspecific bonds (London and van der Waals forces). In contrast, chemical adsorption involves specific chemical bonds (electrostatic, covalent and hydrogen bonds), dipole interactions and hydrophobic interactions [73]. The devices can be organised

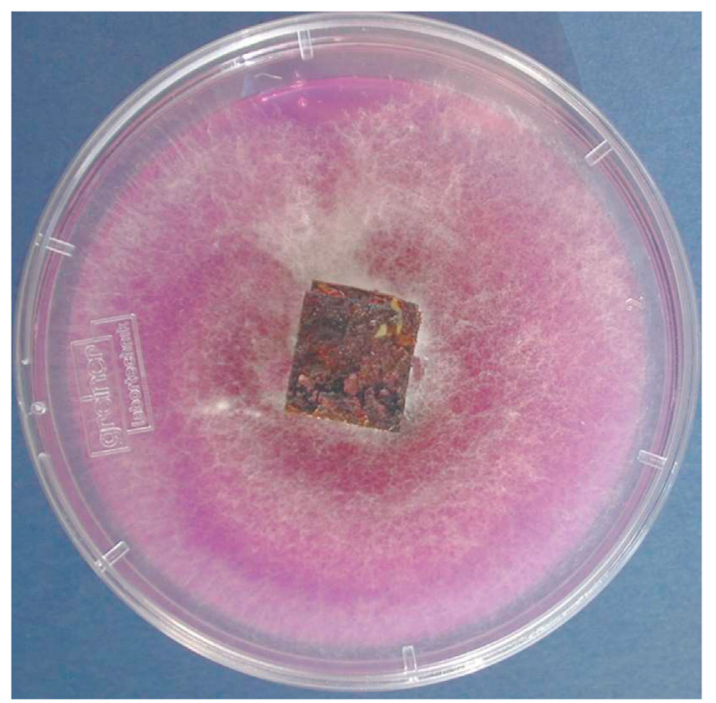

Fig. 1. Example of a cast-iron coupon $(\sim 15 \times 15 \mathrm{~mm})$ cut out from a water distribution system pipe in direct contact with NGRBA medium, showing the growth of a filamentous fungus. Source from the authors. repeatedly within an operational DWDS, allowing biofilms to grow in situ without removing the original pipe. For the isolation and identification of fungi from biofilms, the methodology was usually culture-dependent, the same as for fungi in bulk water. Nevertheless, these methods have several limitations such as temperature and incubation time which will culminate in the recovery of different fungal genera and species [74]. Consequently, the use of culture-independent methods has gained vital relevance to complement culture-dependent methods, or to detect and directly quantify fungal DNA in water. Among these methods are, for instance, Real Time Quantitative PCR (qPCR) and Denaturing Gradient Gel Electrophoresis (DGGE) [17,75]. A growing number of studies have also been using metagenomic approaches for the detection of fungi in bulk water or biofilm samples [7,57,68,75]. Different next generation sequencing (NGS) techniques (e.g. Ilumina and Nanopore) have been applied. The use of these techniques has allowed to understand and enhance not only the knowledge of fungal presence in water (can detect less abundant microorganisms) but also the microbial ecology of these ecosystems. This information has emphasised the need to understand and develop new indicators with the potential to be used to protect and promote water quality and safety [7]. For this reason, Hull et al. [76] highlighted the need to initiate and conduct a large-scale coordinated drinking water microbiome project.

\section{Fungal-bacterial interactions in biofilms}

DWDS biofilms are complex communities with a high number of co-inhabiting microorganisms. This diversity leads to a variety of complex relationships involving inter- and intra-species interactions $[3,7,57]$. Although intra-species interactions may play an important role in the coexistence of some microbiomes, biotic interactions between distantly related organisms across the kingdoms of life also regulate the composition of these communities [77]. In many microbiomes, bacteria can coexist with different eukaryotic microorganisms, including fungi [78]. These interactions encompass, of course, biofilms (Fig. 2). As the microorganisms are closely embedded in an extracellular matrix, inter-kingdom biofilms containing bacteria and filamentous fungi can be considered a closer level of fungal-bacterial interaction, but this aspect is still poorly understood [78]. Different factors may affect these interkingdom interactions, including the presence of quorum sensing (QS) molecules. QS is a mechanism employed by microbial species to coordinate community behaviour. It relies on the production, release and detection of small signalling molecules, which in turn modify gene expression [79]. There are several types of QS signals: Gram-negative bacteria utilize $N$-acyl-homoserine lactones (AHLs)type signals, whereas Gram-positive species use short oligopeptide signals. These QS systems are already well understood at the molecular level and reviewed elsewhere [80,81]. QS controls and regulates different bacterial population density-dependent processes, including biofilm formation, stress resistance, production of toxins and secondary metabolites and pathogenicity [82,83]. In contrast, eukaryotes, and in the scope of this review, filamentous fungi, have the ability to interfere with bacterial communication by producing molecular signals that interact with bacterial QS. These compounds are called quorum sensing inhibitors (QSI). They can mimic the structure or function of autoinducers, act as antagonists to the QS molecules as well as interfere with the stability and function of the regulator protein or the autoinducer synthase and hydrolysate signalling molecules [84]. As filamentous fungi do not have an active immune system, they must rely instead on chemical defence mechanisms. For this reason, they have been studied regarding their QSI potential, in particular the genus Penicillium. Patulin and penicillic acid were identified as being biologically 


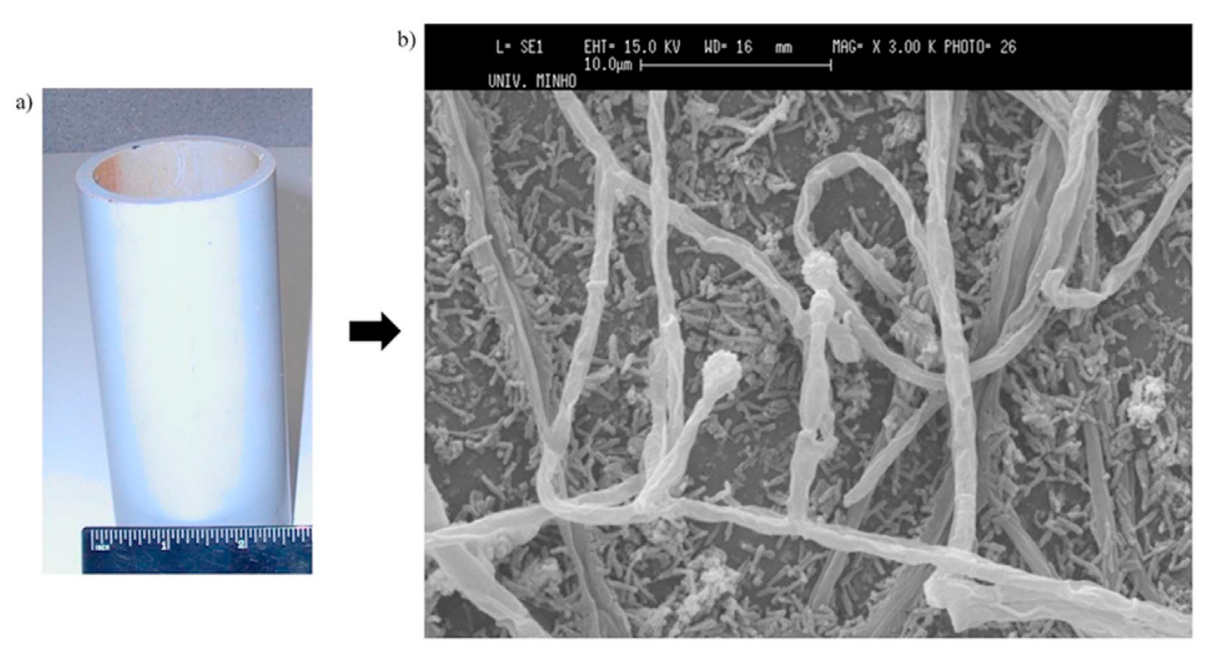

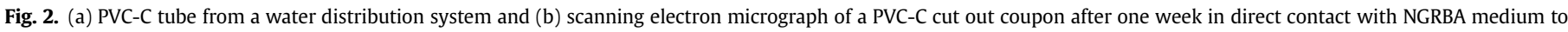
promote the fungi growth only, showing in the basal layer a close relationship between filamentous fungi and bacteria. Source from the authors.

active QSI compounds [79]. Through DNA micro-array-based transcriptomics, the same authors showed that these QSI compounds down-regulated QS-regulated genes in Pseudomonas aeruginosa by $45 \%$ and $60 \%$, respectively, indicating their specificity towards QS-regulated gene expression [79].

Different studies have found different relationships between fungi and bacteria. In mixed biofilms, both organisms can exist as dual complexes or fungi may offer biotic support for the establishment of a bacterial biofilm [85]. However, it has also been shown that fungi often colonize pre-established bacterial biofilms, and due to their different ecological requirements, it has been suggested that it can lead to a positive relationship between these microorganisms [28]. Reports of negative relationships may be observed due to culturing processes, where both fungi and bacteria are in direct competition for resources [41]. This variety in findings could, in sum, be a consequence from several factors, such as the difference in the composition of isolated species from the water systems, differences in methodologies or different biological mechanisms at play [6]. For this reason, a need arises for further research to explore the different correlations between fungi and bacteria and what are the factors influencing these interactions.

To demonstrate the heterogeneity in findings, in a single study, performed on bacterial-fungal biofilms in flowing water photoprocessing tanks using a model community, it was difficult to determine which interactions were present. Some species showed increased growth rate in mixed cultures while others showed a reduction, however, all species were present in a lower number than in single cultures, which was considered to be a result of limitation and competition for the nutrients available [86]. Douterelo et al. [57] reported a positive coexistence between the bacteria Pseudomonas and the fungi Basidiobolus in in situ biofilms. This could be due to ability of the fungi to produce extracellular enzymes that allow them to degrade high molecular weight compounds, releasing secondary metabolites that can potentially be used, in this case, by Pseudomonas [57]. In another study, a correlation was observed between the relative abundance of certain bacterial taxa such as Proteobacteria and Basidiomycota [3]. The same study also confirmed the presence of Acremonium and Neocomospora from early stages of biofilm formation to a more developed biofilm, forming essential communities with bacteria. Fungal contribution, in particular Ascomycota, is very important to the microbial ecology of real DWDS [7]. One of the roles of filamentous fungi in drinking water biofilms has consequently been associated with providing building blocks and/or biotic support through their hyphae for the establishment and colonization of surfaces by bacteria [7]. A recent study performed by Del Olmo et al. [59] detected a core microbial community throughout the network of a DWDS with microorganisms like Pseudomonas, Aspergillus or Alternaria being abundant in underlying and more consolidated material layers. This study revealed a diverse community of fungi which demonstrated a strong contribution to biofilm formation in DWDS, supporting concepts of mutual beneficial fungal-bacterial interactions. In addition, fungal-bacterial communities were found to be highly correlated, with bacteria being more diverse, whilst fungi showing more dominance and stability [59]. Pipe material has also been shown to influence microbial community composition, particularly bacteria [72]. Microbial communities from cast-iron pipes revealed to be more stable than communities from non-ferrous pipe materials [72].

To understand and try to clarify fungal-bacterial interactions in biofilms, several studies have recently been done under controlled laboratory conditions. These studies usually involve the interaction between one fungal and one bacterial species, as the effects observed will result directly from their interactions. In Penicillium expansum inter-kingdom biofilm formation with Acinetobacter calcoaceticus, it was observed that intertwined fungal hyphae increased the cell number of this bacterium, revealing a possible protective role of the fungi towards bacteria. Despite this protective effect, it was observed that when inoculated at the same time, bacteria could inhibit filamentous fungal spore germination and its development into a biofilm in the first $24 \mathrm{~h}$ of interaction [87]. Similar results were obtained in other studies with different microorganisms. For instance, in a $24 \mathrm{~h}$ co-culture study between the bacteria $P$. aeruginosa and the fungus $A$. fumigatus, direct contact between these two microorganisms as well as between the fungi and bacterial supernatant, resulted in an inhibition of fungal biofilm formation [88]. In another $24 \mathrm{~h}$ co-culture study, this bacterium was also able to inhibit spore germination of the fungus Rhizopus microsporus [89]. Fungal spore germination and hyphal development of several Aspergillus species were inhibited when in co-culture with the bacterium Klebsiella pneumoniae [90]. Additionally, the bacterium Staphylococcus aureus strongly inhibited fungal conidiation, filamentation and consequently biofilm formation of A. fumigatus by direct cell-cell contact [91]. This same bacterium was also able to negatively influence the filamentation and biofilm formation of the fungus Fusarium falciforme [92]. Most 
of these studies were performed within $24 \mathrm{~h}$ of interaction, however, with medium renewal and removal of planktonic cells, after that time, an increase in fungal viability could be observed, which could lead to its germination and development into a biofilm [87]. Nogueira et al. [90] also showed that Aspergillus species remain viable after interaction with bacterial cells. This is particularly noteworthy because if the possibility of biofilm formation is provided for the fungi, or if a pre-established fungal biofilm is present, then, an advantage may also be given to opportunistic bacteria to replicate and proliferate in inter-kingdom biofilms inside DWDS. Flemming et al. [4] suggested that it is possible that drinking water biofilms can also help to inhibit the propagation of invading pathogens, thus safeguarding water quality. Understanding community dynamics, including the presence of fungi in DWDS can be the key to sustaining a beneficial and ultimately safe microbiome [59]. A practical example of this statement was observed in a study performed by Lahaye et al. [93] where the treatment of a DWDS of a pig farm using essential oils lead to the evolution of a positive bacterial biofilm. While the initial biofilms were essentially composed of fungi with hyphae being prominent, after treatment with essential oils, a decay of fungal population was observed to the benefit of new bacterial populations. This inversion of the biofilm lead to an improvement of the pig herd's health without addition of antibiotics by allowing a positive biofilm to colonize the water network while also having associated positive economic effects [93]. Several new approaches are also being undertaken to help the removal of pathogenic microorganisms from DWDS. For instance, direct potable reuse requires extensive advanced treatment of wastewater, which often involves combinations of ozonation, granular activated carbon filtration, microfiltration, reverse osmosis and an UV advanced oxidation process [94]. The granular activated carbon filter used in a study performed by Miller et al. [95] harboured an active and consistent microbial community over time. From a treatment process perspective, these filters used in a last stage can act as an additional barrier for organic pollutants while not increasing concentrations of opportunistic pathogens relative to conventional water systems. A diverse microbial community should lead to increased biological stability, capable of outcompeting opportunistic pathogens [95]. Because advance treatment decreases bacterial presence and diversity, treatments such as granular activated carbon filters should be used to increase finished water biostability [95].

\section{Concluding remarks}

Filamentous fungi are present in all environments, and water distribution systems are no exception. Several studies have demonstrated the presence of these microorganisms, including concerning pathogenic, toxigenic or/and allergenic species. The present work provides an updated overview of the occurrence of filamentous fungi in DWDS from the past two decades. Emphasis was given to biofilm formation along with the interaction with bacteria in fungal-bacterial biofilms. Several gaps and drawbacks were detected from the start and some recommendations arise from these needs.

Detection and/or isolation of filamentous fungi in DWDS should follow a uniform approach. Different methodologies, including culturomics and culture-independent methods, should be used to complement one another. Looking at community analysis, NGS techniques have a fundamental role and are also of great importance to analyse interactions between microorganisms. Even with some advances in the study of fungal-bacterial interactions, much more work is needed to fully elucidate these interactions. With differences in the methodology being used and the microorganisms being studied, there is a complex variety of observable relationships. For this reason, there is a necessity to further investigate the different interactions between fungi and bacteria in DWDS and what factors are affecting such associations.

\section{Funding}

Tiago B. Afonso acknowledges the grant provided by the Portuguese Foundation for Science and Technology (FCT) under grant no. PD/BD/128033/2016. Furthermore, this study was also supported by FCT under the scope of the strategic funding of UIDB/ 04469/2020 unit and BioTecNorte operation (NORTE-01-0145FEDER-000004) funded by the European Regional Development Fund under the scope of Norte2020 - Programa Operacional Regional do Norte.

\section{Conflict of interest}

No conflict of interest was reported by the authors.

\section{References}

[1] UN. The sustainable development goals report. available at: https://unstats.un. org/sdgs/report/2020/The-Sustainable-Development-Goals-Report-2020.pdf. [Accessed 9 June 2020].

[2] Simões LC, Simões M. Biofilms in drinking water: problems and solutions. RSC Adv 2013;3:2520-33.

[3] Douterelo I, Fish KE, Boxall JB. Succession of bacterial and fungal communities within biofilms of a chlorinated drinking water distribution system. Water Res 2018;141:74-85.

[4] Flemming HC, Percival SL, Walker JT. Contamination potential of biofilms in water distribution systems. Water Sci Technol Water Supply 2002;2:271-80.

[5] Paterson RRM, Lima N. Fungal contamination of drinking water. In: Lehr J, Keeley J, Lehr J, Kingery III TB, editors. Water encyclopedia, New York; 2005. p. $1-7$.

[6] Sonigo P, De Toni A, Reilly K. Defra A review of fingi in drinking water and the implications for human health. Rev Lit Arts Am 2011;33:1-107.

[7] Douterelo I, Calero-Preciado C, Soria-Carrasco V, Boxall JB. Whole metagenome sequencing of chlorinated drinking water distribution systems. Environ Sci Water Res Technol 2018;4:2080-91.

[8] Bryers JD, Ratner BD. Bioinspired implant materials befuddle bacteria. ASM News 2004;70:232-7.

[9] Simões LC, Simões M, Vieira MJ. Influence of the diversity of bacterial isolates from drinking water on resistance of biofilms to disinfection. Appl Environ Microbiol 2010;76:6673-9.

[10] Viegas C, Pinheiro AC, Sabino R, Viegas S, Brandão J, Veríssimo C. Environmental Mycology in Public Health - Fungi and Mycotoxins Risk Assessment and Management. Academic Press; 2016.

[11] Hibbett DS, Binder M, Bischoff JF, Blackwell M, Cannon PF, Eriksson OE, et al. A higher-level phylogenetic classification of the Fungi. Mycol Res 2007;111: 509-47.

[12] Jones MDM, Forn I, Gadelha C, Egan MJ, Bass D, Massana R, et al. Discovery of novel intermediate forms redefines the fungal tree of life. Nature 2011;474: 200-4.

[13] Lima N, Santos C. MALDI-TOF MS for identification of food spoilage filamentous fungi. Curr Opin Food Sci 2017;13:26-30.

[14] Kirk PM, Cannon PF, David JC, Stalpers JA. Ainsworth \& bisby's dictionary of the Fungi. $9^{\text {th }}$ edition. Wallingford: CAB International; 2001.

[15] Sammon NB, Harrower KM, Fabbro LD, Reed RH. Three potential sources of microfungi in a treated municipal water supply system in sub-tropical Australia. Int J Environ Res Publ Health 2011;8:713-32.

[16] Hageskal G, Gaustad P, Heier BT, Skaar I. Occurrence of moulds in drinking water. J Appl Microbiol 2007;102:774-80.

[17] Al-gabr HM, Zheng T, Yu X. Occurrence and quantification of fungi and detection of mycotoxigenic fungi in drinking water in Xiamen City, China. Sci Total Environ 2014;466-467:1103-11.

[18] Bai X, Zhang T, Ou Z, Li H, Yang Z. Contribution of filamentous fungi to the musty odorant 2,4,6-trichloroanisole in water supply reservoirs and associated drinking water treatment plants. Chemosphere 2017;182:223-30.

[19] Oliveira BR, Mata AT, Ferreira JP, Barreto Crespo MT, Pereira VJ, Bronze MR. Production of mycotoxins by filamentous fungi in untreated surface water. Environ Sci Pollut Res 2018;25:17519-28.

[20] Jones EBG. Fungal adhesion. Mycol Res 1994;98:961-81.

[21] Simões LC, Simões M, Lima N. Kinetics of biofilm formation by drinking water isolated Penicillium expansum. Biofouling 2015;31:349-62.

[22] Harding MW, Marques LLR, Howard RJ, Olson ME. Can filamentous fungi form biofilms? Trends Microbiol 2009; 17:475-80. 
[23] Fernandes S, Simões LC, Lima N, Simões M. Adhesion of filamentous fungi isolated from drinking water under different process conditions. Water Res 2019;164.

[24] Zampieri F, Wösten HAB, Scholtmeijer K. Creating surface properties using a palette of hydrophobins. Materials 2010;3:4607-25.

[25] Blankenship JR, Mitchell AP. How to build a biofilm: a fungal perspective. Curr Opin Microbiol 2006;9:588-94.

[26] Siqueira VM, Oliveira HMB, Santos C, Paterson RRM, Gusmão NB, Lima N. Biofilms from a Brazilian water distribution system include filamentous fungi. Can J Microbiol 2013;59:183-8.

[27] Kinsey GC, Paterson RR, Kelley J. Methods for the determination of filamentous fungi in treated and untreated waters. J Appl Microbiol Symp Suppl 1999: 85.

[28] Doggett MS. Characterization of fungal biofilms within a municipal water distribution system. Appl Environ Microbiol 2000;66:1249-51.

[29] Arvanitidou M, Kanellou K, Constantinides TC, Katsouyannopoulos V. The occurrence of fungi in hospital and community potable waters. Lett Appl Microbiol 1999;29:81-4.

[30] Arvanitidou M, Spaia S, Velegraki A, Pazarloglou M, Kanetidis D, Pangidis P, et al. High level of recovery of fungi from water and dialysate in haemodialysis units. J Hosp Infect 2000;45:225-30.

[31] Göttlich E, Van Der Lubbe W, Lange B, Fiedler S, Melchert I, Reifenrath M, et al. Fungal flora in groundwater-derived public drinking water. Int J Hyg Environ Health 2002;205:269-79.

[32] Warris A, Gaustad P, Meis JFGM, Voss A, Verweij PE, Abrahamsen TG. Recovery of filamentous fungi from water in a paediatric bone marrow transplantation unit. J Hosp Infect 2001;47:143-8.

[33] Anaissie EJ, Stratton SL, Dignani MC, Summerbell RC, Rex JH, Monson TP, et al. Pathogenic Aspergillus species recovered from a hospital water system: a 3year prospective study. Clin Infect Dis 2002;34:780-9.

[34] Anaissie EJ, Stratton SL, Dignani MC, Lee CK, Summerbell RC, Rex JH, et al. Pathogenic molds (including Aspergillus species) in hospital water distribution systems: a 3-year prospective study and clinical implications for patients with hematologic malignancies. Blood 2003;101:2542-6.

[35] Anaissie EJ, Kuchar RT, Rex JH, Francesconi A, Kasai M, Müller FC, et al. Fusariosis associated with pathogenic Fusarium species colonization of a hospital water system: a new paradigm for the epidemiology of opportunistic mold infections. Clin Infect Dis 2001;33:1871-8.

[36] Panagopoulou P, Filioti J, Petrikkos G, Giakouppi P, Anatoliotaki M, Farmaki E, et al. Environmental surveillance of filamentous fungi in three tertiary care hospitals in Greece. J Hosp Infect 2002;52:185-91.

[37] Grabińska-Łoniewska A, Koniłłowicz-Kowalska T, Wardzyńska G, Boryn K. Occurrence of fungi in water distribution system. Polish J Environ Stud 2007; 16:539-47.

[38] Hageskal G, Knutsen AK, Gaustad P, De Hoog GS, Skaar I. Diversity and significance of mold species in Norwegian drinking water. Appl Environ Microbiol 2006;72:7586-93.

[39] Hageskal G, Vrålstad T, Knutsen AK, Skaar I. Exploring the species diversity of Trichoderma in Norwegian drinking water systems by DNA barcoding. Mol Ecol Resour 2008;8:1178-88.

[40] Hapcioglu B, Yegenoglu Y, Erturan Z, Nakipoglu Y, Issever H. Heterotrophic bacteria and filamentous fungi isolated from a hospital water distribution system. Indoor Built Environ 2005;14:487-93.

[41] Gonçalves AB, Paterson RRM, Lima N. Survey and significance of filamentous fungi from tap water. Int J Hyg Environ Health 2006;209:257-64.

[42] Hayette MP, Christiaens G, Mutsers J, Barbier C, Huynen P, Melin P, et al. Filamentous fungi recovered from the water distribution system of a Belgian university hospital. Med Mycol 2010;48:969-74.

[43] Kanzler D, Buzina W, Paulitsch A, Haas D, Platzer S, Marth E, et al. Occurrence and hygienic relevance of fungi in drinking water. Mycoses 2008;51:165-9.

[44] Varo SD, Martins CHG, Cardoso MJDO, Sartori FG, Montanari LB, PiresGonçalves RH. Isolamento de fungos filamentosos em água utilizada em uma unidade de hemodiálise. Rev Soc Bras Med Trop 2007;40:326-31.

[45] Pires-Gonçalves RH, Sartori FG, Montanari LB, Zaia JE, Melhem MSC, MendesGiannini MJS, et al. Occurrence of fungi in water used at a haemodialysis centre. Lett Appl Microbiol 2008;46:542-7.

[46] Pereira VJ, Basílio MC, Fernandes D, Domingues M, Paiva JM, Benoliel MJ, et al. Occurrence of filamentous fungi and yeasts in three different drinking water sources. Water Res 2009;43:3813-9.

[47] Pereira VJ, Fernandes D, Carvalho G, Benoliel MJ, San Romão MV, Barreto Crespo MT. Assessment of the presence and dynamics of fungi in drinking water sources using cultural and molecular methods. Water Res 2010;44: 4850-9.

[48] Sammon NB, Harrower KM, Fabbro LD, Reed RH. Incidence and distribution of microfungi in a treated municipal water supply system in sub-tropical Australia. Int J Environ Res Publ Health 2010;7:1597-611.

[49] Mesquita-Rocha S, Godoy-Martinez PC, Gonçalves SS, Urrutia MD, Carlesse F, Seber A, et al. The water supply system as a potential source of fungal infection in paediatric haematopoietic stem cell units. BMC Infect Dis 2013;13.

[50] Oliveira BR, Barreto Crespo MT, San Romão MV, Benoliel MJ, Samson RA, Pereira VJ. New insights concerning the occurrence of fungi in water sources and their potential pathogenicity. Water Res 2013;47:6338-47.

[51] Schiavano GF, Parlani L, Sisti M, Sebastianelli G, Brandi G. Occurrence of fungi in dialysis water and dialysate from eight haemodialysis units in central Italy. J Hosp Infect 2014;86:194-200.
[52] Arroyo MG, Frota OP, Peresi JTM, Brizzotti-Mazuchi NS, Ferreira AM, Rigotti MA, et al. Wide diversity of fungal species found in wellwater for human consumption: an analytical cross-sectional study. Sao Paulo Med J 2019;137:512-6.

[53] Ma X, Baron JL, Vikram A, Stout JE, Bibby K. Fungal diversity and presence of potentially pathogenic fungi in a hospital hot water system treated with onsite monochloramine. Water Res 2015;71:197-206.

[54] Oliveira HMB, Santos C, Paterson RRM, Gusmão NB, Lima N. Fungi from a groundwater-fed drinkingwater supply system in Brazil. Int J Environ Res Publ Health 2016;13.

[55] Ma X, Vikram A, Casson L, Bibby K. Centralized drinking water treatment operations shape bacterial and fungal community structure. Environ Sci Technol 2017;51:7648-57.

[56] Hurtado-McCormick S, Sánchez L, Martínez J, Calderón C, Calvo D, Narváez D, et al. Fungi in biofilms of a drinking water network: occurrence, diversity and mycotoxins approach. Water Sci Technol Water Supply 2016;16:905-14.

[57] Douterelo I, Jackson M, Solomon C, Boxall J. Microbial analysis of in situ biofilm formation in drinking water distribution systems: implications for monitoring and control of drinking water quality. Appl Microbiol Biotechnol 2016;100:3301-11.

[58] Góralska K, Błaszkowska J, Dzikowiec M. The occurrence of potentially pathogenic filamentous fungi in recreational surface water as a public health risk. J Water Health 2020;18:127-44.

[59] Del Olmo G, Husband S, Sánchez Briones C, Soriano A, Calero Preciado C, Macian J, et al. The microbial ecology of a Mediterranean chlorinated drinking water distribution systems in the city of Valencia (Spain). Sci Total Environ 2021;754:142016.

[60] Denning DW, O'Driscoll BR, Hogaboam CM, Bowyer P, Niven RM. The link between fungi and severe asthma: a summary of the evidence. Eur Respir J 2006;27:615-26.

[61] Novak Babič M, Zupančič J, Brandão J, Gunde-Cimerman N. Opportunistic water-borne human pathogenic filamentous fungi unreported from food. Microorganisms 2018;6:79.

[62] Paterson RRM. Zearalenone production and growth in drinking water inoculated with Fusarium graminearum. Mycol Prog 2007;6:109-13.

[63] Novak Babič M, Gunde-Cimerman N, Vargha M, Tischner Z, Magyar D, Veríssimo C, et al. Fungal contaminants in drinking water regulation? A tale of ecology, exposure, purification and clinical relevance. Int J Environ Res Publ Health 2017;14.

[64] Siqueira VM, Oliveira HMB, Santos C, Paterson RRM, Gusmão NB, Lima N. Filamentous fungi in drinking water, particularly in relation to biofilm formation. Int J Environ Res Publ Health 2011;8:456-69.

[65] Schoch CL, Seifert KA, Huhndorf S, Robert V, Spouge JL, Levesque CA, et al. Nuclear ribosomal internal transcribed spacer (ITS) region as a universal DNA barcode marker for Fungi. Proc Natl Acad Sci U S A 2012;109:6241-6.

[66] Heinrichs G, Hübner I, Schmidt CK, de Hoog GS, Haase G. Analysis of black fungal biofilms occurring at domestic water taps (I): compositional analysis using tagencoded FLX amplicon pyrosequencing. Mycopathologia 2013;175:387-97.

[67] Stielow JB, Lévesque CA, Seifert KA, Meyer W, Irinyi L, Smits D, et al. One fungus, which genes? Development and assessment of universal primers for potential secondary fungal DNA barcodes. Persoonia Mol Phylogeny Evol Fungi 2015;35:242-63.

[68] Moat J, Rizoulis A, Fox G, Upton M. Domestic shower hose biofilms contain fungal species capable of causing opportunistic infection. J Water Health 2016;14:727-37.

[69] Douterelo I, Boxall JB, Deines P, Sekar R, Fish KE, Biggs CA. Methodological approaches for studying the microbial ecology of drinking water distribution systems. Water Res 2014;65:134-56.

[70] Lin W, Yu Z, Chen X, Liu R, Zhang H. Molecular characterization of natural biofilms from household taps with different materials: PVC, stainless steel, and cast iron in drinking water distribution system. Appl Microbiol Biotechnol 2013;97:8393-401.

[71] Yu J, Kim D, Lee T. Microbial diversity in biofilms on water distribution pipes of different materials. Water Sci Technol 2010;61:163-71.

[72] Douterelo I, Dutilh BE, Arkhipova K, Calero C, Husband S. Microbial diversity, ecological networks and functional traits associated to materials used in drinking water distribution systems. Water Res 2020;173:115586.

[73] Simões LC. Biofilms in drinking water. In: Simões M, Mergulhão F, editors. Biofilms in bioengeneering. New York (NY: Nova Science; 2013. p. 157-89.

[74] Hageskal G, Lima N, Skaar I. The study of fungi in drinking water. Mycol Res 2009;113:165-72.

[75] Novak Babič M, Zalar P, Ženko B, Džeroski S, Gunde-Cimerman N. Yeasts and yeast-like fungi in tap water and groundwater, and their transmission to household appliances. Fungal Ecol 2016;20:30-9.

[76] Hull NM, Ling F, Pinto AJ, Albertsen M, Jang HG, Hong PY, et al. Drinking water microbiome project: is it time? Trends Microbiol 2019;27:670-7.

[77] Kastman EK, Kamelamela N, Norville JW, Cosetta CM, Dutton RJ, Wolfe BE. Biotic interactions shape the ecological distributions of Staphylococcus species. mBio 2016;7:1-13.

[78] Frey-Klett P, Burlinson P, Deveau A, Barret M, Tarkka M, Sarniguet A. Bacterialfungal interactions: hyphens between agricultural, clinical, environmental, and food microbiologists. Microbiol Mol Biol Rev 2011;75:583-609.

[79] Rasmussen TB, Skindersoe ME, Bjarnsholt T, Phipps RK, Christensen KB, Jensen PO, et al. Identity and effects of quorum-sensing inhibitors produced by Penicillium species. Microbiology 2005;151:1325-40. 
[80] Cook LC, Federle MJ. Peptide pheromone signaling in Streptococcus and Enterococcus. FEMS Microbiol Rev 2014:38:473-92.

[81] Papenfort K, Bassler BL. Quorum sensing signal-response systems in Gramnegative bacteria. Nat Rev Microbiol 2016;14:576-88.

[82] Antunes LCM, Ferreira RBR, Buckner MMC, Finlay BB. Quorum sensing in bacterial virulence. Microbiology 2010;156:2271-82.

[83] Shrout JD, Tolker-Nielsen T, Givskov M, Parsek MR. The contribution of cellcell signaling and motility to bacterial biofilm formation. MRS Bull 2011;36: 367-73.

[84] González JE, Keshavan ND. Messing with bacterial quorum sensing. Microbiol Mol Biol Rev 2006;70:859-75.

[85] Seneviratne G, Zavahir JS, Bandara WMMS, Weerasekara MLMAW. Fungalbacterial biofilms: their development for novel biotechnological applications. World J Microbiol Biotechnol 2007;24:739.

[86] Elvers KT, Leeming K, Moore CP, Lappin-Scott HM. Bacterial-fungal biofilms in flowing water photo-processing tanks. J Appl Microbiol 1998;84:607-18.

[87] Afonso TB, Simões LC, Lima N. In vitro assessment of inter-kingdom biofilm formation by bacteria and filamentous fungi isolated from a drinking water distribution system. Biofouling 2019;35:1041-54.

[88] Mowat E, Rajendran R, Williams C, McCulloch E, Jones B, Lang S, et al. Pseudomonas aeruginosa and their small diffusible extracellular molecules inhibit Aspergillus fumigatus biofilm formation. FEMS Microbiol Lett 2010;313: 96-102.
[89] Kousser C, Clark C, Sherrington S, Voelz K, Hall RA. Pseudomonas aeruginosa inhibits Rhizopus microsporus germination through sequestration of free environmental iron. Sci Rep 2019;9:1-14.

[90] Nogueira MF, Pereira L, Jenull S, Kuchler K, Lion T. Klebsiella pneumoniae prevents spore germination and hyphal development of Aspergillus species. Sci Rep 2019;9.

[91] Granillo AR, Canales MGM, Espíndola MES, Rivera MAM, De Lucio VMB, Tovar AVR. Antibiosis interaction of Staphylococccus aureus on Aspergillus fumigatus assessed in vitro by mixed biofilm formation. BMC Microbiol 2015;15:33.

[92] Bautista-Hernández LA, Gómez-Olivares JL, Buentello-Volante B, DominguezLopez A, Garfias Y, Acosta-García MC, et al. Negative interaction of Staphylococcus aureus on Fusarium falciforme growth ocular isolates in an in vitro mixed biofilm. Microb Pathog 2019;135.

[93] Lahaye É, Renaux JJ, Le Tilly V, Sire O. Evolution of a fungal ecosystem in a water distribution system to a positive bacterial biofilm subsequent to a treatment using essential oils. Comptes Rendus Chim 2016;19:505-10.

[94] Gerrity D, Pecson B, Shane Trussell R, Rhodes Trussell R. Potable reuse treatment trains throughout the world. J Water Supply Res Technol - AQUA 2013;62:321-38.

[95] Miller SE, Rodriguez RA, Nelson KL. Removal and growth of microorganisms across treatment and simulated distribution at a pilot-scale direct potable reuse facility. Environ Sci Water Res Technol 2020;6:1370-87. 